\title{
CHARACTERIZATION OF TENORM AND SEDIMENTS OF KASTELA BAY AND THE INFLUENCE OF TENORM ON THE QUALITY OF SEDIMENTS
}

\author{
I. LOVRENCIC ${ }^{1^{*}}$ \\ V. ORESCANIN ${ }^{1}$ \\ D. BARISIC ${ }^{1}$ \\ L. MIKELIC ${ }^{1}$ \\ M. ROZMARIC MACEFAT ${ }^{1}$ \\ S. LULIC ${ }^{1}$ \\ G. PAVLOVIC ${ }^{2}$
}

\author{
${ }^{1}$ Laboratory for Radioecology \\ Division for Marine and Environmental Research \\ Institute Rudjer Boskovic, Bijenicka cesta 54 \\ 10002 Zagreb, Croatia \\ ${ }^{2}$ Faculty of Science, Univesitiy of Zagreb \\ Department of Mineralogy and Petrography \\ Horvatovac bb, 10000 Zagreb, Croatia
}

Selected from papers presented in $9^{\text {th }}$ International Conference on Environmental Science and Technology (9CEST2005)

1-3 September 2005, Rhodes island, Greece

\author{
*to whom all correspondence should be addressed \\ Tel: +385-1-4560933; Fax+385-1-4680205 \\ e-mail: ivanka.lovrencic@irb.hr
}

\begin{abstract}
The objective of this study was set on three goals: (i) Chemical and radiological characterization and leaching properties of the mixture of fly and bottom ash, (ii) Chemical, radiological and mineralogical characterization of the Kastela Bay sediments, and (iii) Estimation of the influence of TENORM deposition on the quality of sediments. Samples of the mixture of fly and bottom ash, sediment cores ranging from 0 to $55 \mathrm{~cm}$ and surface sediment samples were analyzed. Enrichment with heavy metals in the mixture of fly and bottom ash ranged from 1.6 to 36 times while ${ }^{226} \mathrm{Ra}$ and ${ }^{238} \mathrm{U}$ were up to 50 times enriched. Most of the measured heavy metals in the ash were 3-4 times those in the surrounding soil. It was found that over $37 \%$ of the total $U$ could be removed from the ash by the sea water. The highest enrichment in sediment cores was found for Zn (35.6 times), $\mathrm{Pb}$ (16 times), $\mathrm{Cr}$ (9.1 times) and $\mathrm{Ni}(4$ times). The highest concentrations of total uranium were determined at positions in the vicinity of the ash deposit site. Maximum concentrations of heavy metals were found in deeper sediment segments deposited in the period of the highest industrial production.
\end{abstract}

KEYWORDS: TENORM, fly ash, bottom ash, radionuclides, heavy metals, Kastela Bay

\section{INTRODUCTION}

The purpose of this paper was chemical, radiological and mineralogical characterization of the Kastela Bay sediments under the influence of past industrial activity and its waste by-products. The Kastela Bay is situated in the Middle Adriatic and represents a semienclosed low energy environment with total area of $60 \mathrm{~km}^{2}$, average depth of $23 \mathrm{~m}$ (maximum depth of $45 \mathrm{~m}$ at the inlet of the bay), and the volume of $1.4 \mathrm{~km}^{3}$ (Ujevic et al., 2000). Until the early 90's of the twentieth century this was densely populated and the most industrialized area along the eastern Adriatic coast. The major sources of pollution were ex-chemical factory called "Adriavinil" cement plant, iron plant, shipyard and electroplating facility. Heavy traffic across the main road located close to the shoreline also contributes to the pollution of the Bay. Besides, most of the outlets of industrial and domestic wastewater, located in the eastern part of the Bay, discharge their untreated or partially treated effluents into the Bay either directly or through the Jadro River. 
As a result of almost five decades of "Adriavinil" factory operation, large amount of the mixture of fly and bottom ash, by-products of coal burning in thermo electric unit of the factory, remained. All of the used coals have elevated concentrations of uranium and its natural decay series radionuclide products. During the combustion process and depending on the inorganic portion of the coal, content of ${ }^{226} \mathrm{Ra}$ and ${ }^{238} \mathrm{U}$ in fly and bottom ash was elevated several times. Bottom and fly ash were, as a produced waste, deposited in the vicinity of the facility and remained there until 1973 when a proper deposition location was defined. The material was removed on selected location few hundred meters farther away at the border of town Kastel Gomilica and protected with plastic foil, layer of clay and humus. The area was fenced in and the grass was sown. That way the "old" depot was formed. In time, the area between the factory and the "old" depot was covered up with waste materials, among it with mixture of fly and bottom ash. At the end of 1980s and the beginning of 1990s, fly and bottom ash were dumped directly into shallow seawater in the south-western part of the facility. In the southern part, a little bit more to the west of the present fence of former "Adriavinil", a floating dock is situated. Most of its parts are buried into the deposited material, which is in direct contact with the sea. In north-south direction a channel is also buried into the fly and bottom ash. At both sides of the channel the mixture of fly and bottom ash is exposed on the surface. In south-western part of the area of the factory a pool separated from the sea is situated. Sea water in the pool is in direct contact with the waste material. It is visible from all documents that natural activity of both uranium isotopes $\left({ }^{238} \mathrm{U}\right.$ and ${ }^{235} \mathrm{U}$ ) as well as of ${ }^{226} \mathrm{Ra}$ and their decay products is elevated both in fly and bottom ash (personal communication, data not published). Therefore, this waste material can be characterized as TENORM (Technologically Enhanced Naturally Occurring Radioactive Material) because concentrations (activities) of natural radionuclides $\left({ }^{238} U,{ }^{235} \mathrm{U}\right.$ and ${ }^{226} \mathrm{Ra}$ ) are elevated by a technological procedure. To obtain a preliminary data about the present state of new unregulated part of the depot, 33 samples of TENORM were collected and analyzed in spring 2004.

\section{MATERIALS AND METHODS}

At each location, $1 \mathrm{~kg}$ of the mixture of fly and bottom ash was sampled. Material was dried at $105^{\circ} \mathrm{C}$ and fraction $<0.5 \mathrm{~mm}$ was disaggregated in an agate mortar and prepared for determination of total elemental composition, selected radionuclides, mineralogical composition as well as for leaching tests.

Twelve sediment profiles and nine surface samples were collected in Kastela Bay. Geographical location of the study area and the sampling points are shown in Figure 1.

Sediment cores were divided into segments of 0-5 cm, 5-10 cm, $10-20 \mathrm{~cm}, 20-30 \mathrm{~cm}, 30-$ $40 \mathrm{~cm}$ and $40-50 \mathrm{~cm}$ (or $40-55 \mathrm{~cm}$ if possible). Concentrations of $\mathrm{Cr}, \mathrm{Fe}, \mathrm{Zn}, \mathrm{Zr}, \mathrm{Pb}, \mathrm{Ni}$, $C o$ and $U$ in bulk samples of ash and sediments were determined using energy dispersive X-ray fluorescence, EDXRF method (Orescanin et al., 2003). Cu was measured only in the mixture of fly and bottom ash. Samples were irradiated by X-rays generated from a ${ }^{109} \mathrm{Cd}$ annular source. The incident angle was $49.76^{\circ}$. Detection of characteristic X-ray radiation from the sample was conducted with a $\mathrm{Si}$ ( $\mathrm{Li}$ ) detector (Canberra) cooled with the liquid nitrogen and with the following characteristics: detector size $=30 \mathrm{~mm}^{2}$, Si thickness $=3 \mathrm{~mm}$, Be window $=25 \mu \mathrm{m}$, FWHM for $5.9 \mathrm{KeV}{ }^{55} \mathrm{Fe} 165$ $\mathrm{eV}$. The emerging angle was $74.05^{\circ}$, and the distance was $1.5 \mathrm{~cm}$. Spectra were collected by a Genie-2000 software (Canberra). Collecting time was $10000 \mathrm{~s}$ for thin targets and $7000 \mathrm{~s}$ for thick targets (solid ash samples and sediment samples). Spectral data were analyzed by WinAxil software (Canberra). Calibration file for the thin targets was created on the basis of measurements of the standard solutions (Merck) prepared and analyzed in the same way as unknown samples. Elemental concentrations in the 
thick targets were calculated with the "Fundamental parameters" method from a WinFund package using $\mathrm{ECH}$ (coal burning fly ash) as a standard reference material.
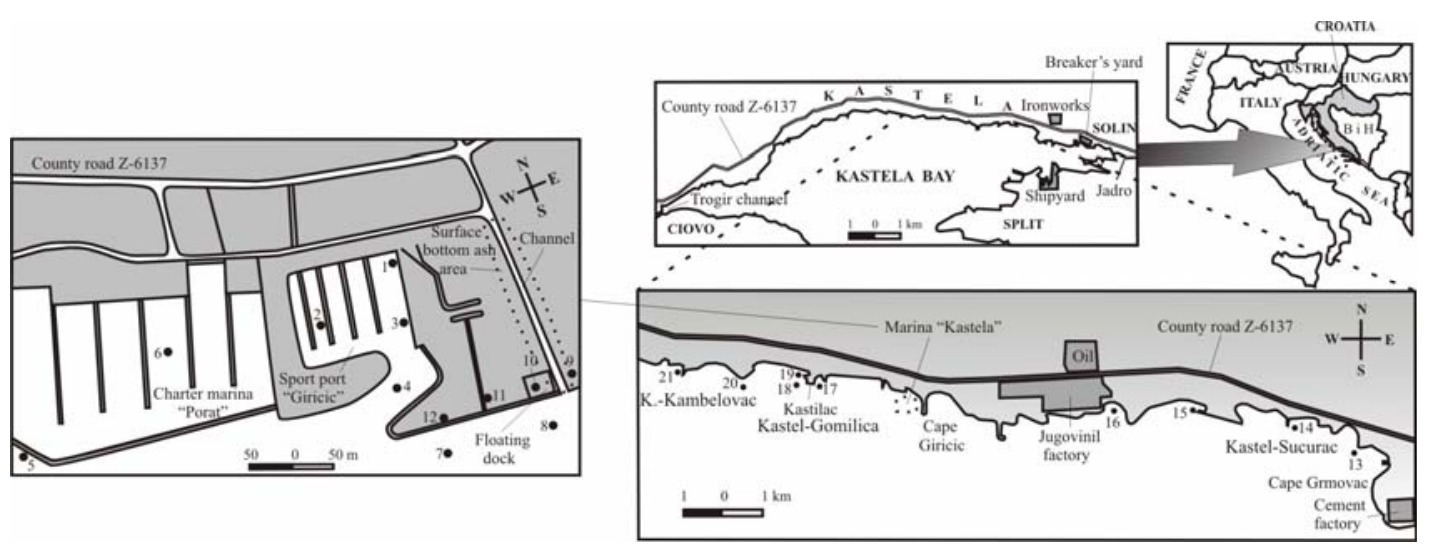

Figure 1. Geographical location of the study area and the sampling points

After the XRF analysis, $1 \mathrm{~g}$ of homogenized sample was extracted either by distilled water or by sea water. Solid part was separated from the leachate by filtration through the white ribbon-filter paper. The extracts were diluted to $100 \mathrm{ml}$ with double distilled water, divided in two sub samples, and adjusted to $\mathrm{pH} 3$ and 11 respectively. After 20 minutes of complexation with APDC (ammonium-pyroloidinedithiocarbamate), the suspension was filtered through a Millipore filter $(0.45 \mu \mathrm{m})$ and irradiated for $10000 \mathrm{~s}$. Also, different organic acids were applied in order to simulate leaching conditions that occur naturally in the environment. $1 \mathrm{~g}$ of homogenized samples were extracted by $1 \mathrm{M} \mathrm{NH}_{4} \mathrm{Ac}-\mathrm{pH} 7$ for one hour or by $2 \times 10^{-2} \mathrm{M}$ citric acid, EDTA, ascorbic or oxalic acid for eight hours.

All sediment segments from 0-5 $\mathrm{cm}$ were also prepared for XRD analysis. Powdered samples were examined at room temperature using a Philips PW 1830 X-ray diffractometer with $\mathrm{Cu}$ tube (current $=40 \mathrm{~mA}$; voltage $=40 \mathrm{kV}$ ), graphite crystal monocromator and proportional counter. Diffraction data were processed by Philips $X ' P e r t$ software. The relative intensities of X-ray diffraction lines were compared with literature values (Orescanin et al., 2004b).

Ash and sediment materials were placed in the counting containers of $125 \mathrm{~cm}^{3}$, sealed and stored for at least the 4-week period to allow an ingrowth period of gaseous ${ }^{222} \mathrm{Rn}$. At the end of the ingrowth period, gamma-spectrometry measurements were performed on a HPGe semiconductor detector joined to the 8192 channel analyzer "Canberra". Spectra were recorded during 80000 seconds and analyzed using Genie 2K "Canberra" software. Activities of ${ }^{40} \mathrm{~K}$ were calculated from the $1460.75 \mathrm{keV}$-peak, ${ }^{226} \mathrm{Ra}$ from the $609.3 \mathrm{keV}$ peak of its ${ }^{214} \mathrm{Bi}$ progeny and ${ }^{228} \mathrm{Ra}$ from $911.1 \mathrm{keV}$-peak of its ${ }^{228} \mathrm{Ac}$ progeny. Activities of ${ }^{235} \mathrm{U}$ were calculated from $186 \mathrm{keV}$-peak after subtraction of the overlapping ${ }^{226} \mathrm{Ra}$ contribution and used for calculation of ${ }^{238} \mathrm{U}$ activity assuming the natural ${ }^{235} \mathrm{U} /{ }^{238} \mathrm{U}$ activity ratio of 0.04603 (Orescanin et al., 2004a; Marinez-Lobo and Palomares 1991; Murray and Aitken, 1988).

\section{RESULTS}

\section{Characterization of the mixture of fly and bottom ash}

Table 1 presents the mean values and the concentration ranges of selected elements determined in 33 samples of the mixture of fly and bottom ash and Figure 2 activities of the radionuclides ${ }^{226} \mathrm{Ra}$ and ${ }^{238} \mathrm{U}$ determined in the same samples. The results of the leaching tests are shown in Table 2. 
Table 1. Mean values $(\bar{X})$ and concentration ranges measured in the mixture of fly and bottom ash from Kastel Gomilica, Croatia; mean values of the elements for common flysch soil and ratio between ash and soil mean values

\begin{tabular}{lcccc}
\hline Element & $\overline{\mathbf{X}}$ & Range & $\overline{\mathbf{X}}$ soil & $\overline{\mathbf{X}}_{\text {ash }} \boldsymbol{I} \overline{\mathbf{X}}_{\text {soil }}$ \\
\hline $\mathrm{Zn}(\mathrm{ppm})$ & 150.5 & $56.0-307.0$ & 155.9 & 1.0 \\
$\mathrm{Cu}(\mathrm{ppm})$ & 40.3 & $19.0-64.0$ & 22 & 1.8 \\
$\mathrm{Ni}(\mathrm{ppm})$ & 149.0 & $48.0-240.0$ & 34.3 & 4.3 \\
$\mathrm{Co}(\mathrm{ppm})$ & 11.7 & $4.9-22.8$ & 12.1 & 1.0 \\
$\mathrm{Fe}(\%)$ & 3.775 & $1.260-7.810$ & 4.401 & 0.9 \\
$\mathrm{Cr}(\mathrm{ppm})$ & 136.2 & $69.6-250.0$ & 153.4 & 0.9 \\
$\mathrm{Zr}(\mathrm{ppm})$ & 184.2 & $65.0-281.0$ & 380.6 & 0.5 \\
$\mathrm{U}(\mathrm{ppm})$ & 93.8 & $34.0-227.0$ & 2.6 & 36.1 \\
$\mathrm{~Pb}(\mathrm{ppm})$ & 42.8 & $24.6-74.0$ & 26.6 & 1.6 \\
\hline
\end{tabular}

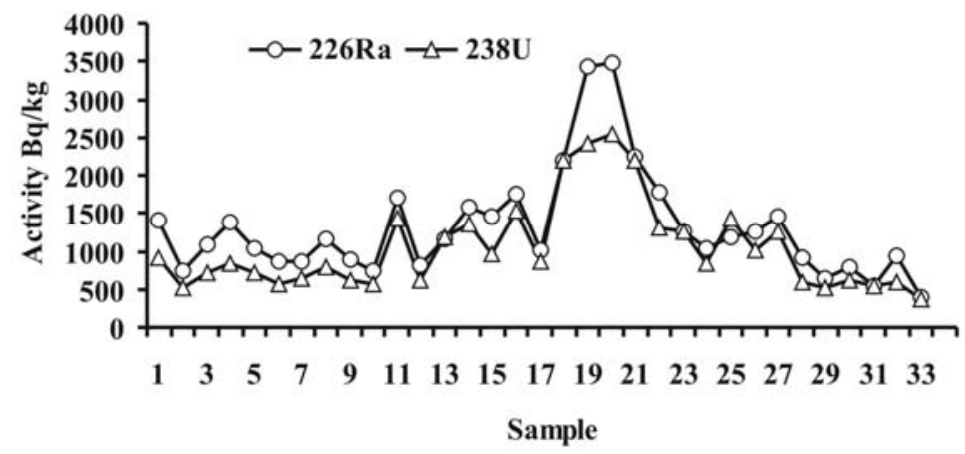

Figure 2. Activities of ${ }^{226} \mathrm{Ra}$ and ${ }^{238} \mathrm{U}$ in 33 samples of the mixture of fly and bottom ash from Kastel Gomilica, Croatia

Table 2: Elemental concentrations measured in the extracts of the composite sample of the mixture of fly and bottom ash and percentages of elements extracted by different extraction agents.

1-extracted with distilled water acording to DIN-38414-S4 standard; 2-extracted with sea water (solid:liguid = 1:10); 3-extracted with $\mathrm{NH}_{4} \mathrm{Ac}$; 4-extracted with ascorbic acid; 5-extracted with EDTA; 6-extracted with citric acid; 7-extracted with oxalic acid; -: test not performed

\begin{tabular}{ccc|ccccc}
\hline & \multicolumn{2}{c|}{$\begin{array}{c}\text { Elemental } \\
\text { concentrations (ppb) }\end{array}$} & \multicolumn{5}{c}{$\begin{array}{c}\text { Percentage of element released from the mixture } \\
\text { of fly and bottom ash }\end{array}$} \\
\hline Element & $\mathbf{1}$ & $\mathbf{2}$ & $\mathbf{3}$ & $\mathbf{4}$ & $\mathbf{5}$ & $\mathbf{6}$ & $\mathbf{7}$ \\
\hline $\mathrm{Pb}$ & 58.4 & 46.8 & 2.5 & 2.0 & 3.1 & 6.7 & 5.4 \\
$\mathrm{U}$ & 882.0 & 29732.0 & 1.6 & 26.4 & 17.2 & 43.2 & 51.2 \\
$\mathrm{Se}$ & 23.1 & 61.9 & - & - & - & - & - \\
$\mathrm{V}$ & 109.2 & 212.4 & 1.7 & 0.8 & 0.1 & 1.2 & 1.8 \\
$\mathrm{Cr}$ & 50.4 & 61.2 & 0.8 & 0.8 & 1.7 & 1.7 & 1.9 \\
$\mathrm{Fe}$ & 134.4 & 151.2 & - & - & - & - & - \\
$\mathrm{Ni}$ & 21.4 & 14.4 & 0.2 & 0.3 & 0.3 & 2.2 & 1.6 \\
$\mathrm{Cu}$ & 31.1 & 24.81 & 1.6 & 1.2 & 7.5 & 6.4 & 3.8 \\
$\mathrm{Zn}$ & 49.11 & 34.6 & 1.7 & 1.7 & 3.2 & 8.5 & 9.8 \\
$\mathrm{Co}$ & 9.2 & n.d. & 2.0 & 4.6 & 0.1 & 9.8 & 8.2 \\
\hline
\end{tabular}

\section{Characterization of sediment samples}

Table 3 shows the activities of ${ }^{226} \mathrm{Ra}$ and ${ }^{238} \mathrm{U}$ measured in 12 sediment profiles. The activities of ${ }^{226} \mathrm{Ra}$ and ${ }^{238} \mathrm{U}$ measured in nine surface samples of Kastela Bay sediments and mean values of selected radionuclides determined for open Adriatic and coastal 
Adriatic sediment are presented in Table 4. Concentrations of selected elements measured in 12 sediment profiles are presented in Table 5.

Table 3. Activities of ${ }^{226} \mathrm{Ra}$ and ${ }^{238} \mathrm{U}$ in $\mathrm{Bq} \mathrm{kg}{ }^{-1}$ measured in 12 sediment profiles

\begin{tabular}{|c|c|c|c|c|c|c|c|}
\hline Profile & $\begin{array}{c}\text { Depth } \\
(\mathrm{cm})\end{array}$ & ${ }^{226} \mathrm{Ra}$ & ${ }^{238} U$ & Profile & $\begin{array}{c}\text { Depth } \\
(\mathrm{cm})\end{array}$ & ${ }^{226} \mathrm{Ra}$ & ${ }^{238} U$ \\
\hline \multirow{6}{*}{1} & $00-5$ & $155.7 \pm 3.3$ & $157.7 \pm 10.7$ & \multirow{6}{*}{7} & $00-5$ & $39.1 \pm 1.9$ & $45.6 \pm 6.8$ \\
\hline & $5-10$ & $540.7 \pm 7.0$ & $378.7 \pm 20.6$ & & $5-10$ & $22.1 \pm 0.9$ & $27.0 \pm 3.5$ \\
\hline & $10-20$ & $260.7 \pm 3.5$ & $184.2 \pm 10.4$ & & $10-20$ & $19.4 \pm 0.9$ & $24.1 \pm 3.4$ \\
\hline & $20-30$ & $117.3 \pm 2.2$ & $108.3 \pm 6.8$ & & $20-30$ & $15.8 \pm 0.8$ & $20.0 \pm 2.9$ \\
\hline & $30-40$ & $176.9 \pm 3.0$ & $170.9 \pm 9.1$ & & $30-40$ & $16.7 \pm 0.8$ & $20.6 \pm 3.0$ \\
\hline & $40-55$ & $647.1 \pm 7.2$ & $446.9 \pm 20.4$ & & & & \\
\hline \multirow{5}{*}{2} & $00-5$ & $123.4 \pm 2.1$ & $75.9 \pm 6.0$ & \multirow{5}{*}{8} & $00-5$ & $20.9 \pm 0.9$ & $22.2 \pm 3.4$ \\
\hline & $5-10$ & $214.5 \pm 2.7$ & $145.1 \pm 8.1$ & & $5-10$ & $21.6 \pm 0.9$ & $20.5 \pm 3.3$ \\
\hline & $10-20$ & $262.3 \pm 3.3$ & $214.5 \pm 10.1$ & & $10-20$ & $18.0 \pm 0.9$ & $20.0 \pm 3.1$ \\
\hline & $20-30$ & $484.9 \pm 4.7$ & $357.3 \pm 13.9$ & & $20-30$ & $19.2 \pm 0.9$ & $19.8 \pm 3.3$ \\
\hline & $30-40$ & $773.0 \pm 6.3$ & $605.6 \pm 17.9$ & & $30-40$ & $20.8 \pm 0.9$ & $18.8 \pm 3.1$ \\
\hline \multirow{5}{*}{3} & $00-5$ & $19.6 \pm 0.8$ & $19.2 \pm 2.8$ & \multirow{5}{*}{9} & $00-5$ & $68.3 \pm 1.9$ & $52.9 \pm 5.7$ \\
\hline & $5-10$ & $13.2 \pm 0.6$ & $11.4 \pm 2.1$ & & $5-10$ & $74.9 \pm 1.7$ & $55.5 \pm 5.2$ \\
\hline & $10-20$ & $24.7 \pm 0.9$ & $21.4 \pm 3.0$ & & $10-20$ & $74.4 \pm 1.7$ & $54.6 \pm 5.1$ \\
\hline & $20-30$ & $30.6 \pm 1.0$ & $22.4 \pm 3.4$ & & $20-30$ & $58.3 \pm 1.5$ & $36.7 \pm 4.3$ \\
\hline & $30-40$ & $16.8 \pm 0.7$ & $16.7 \pm 2.7$ & & $30-40$ & $34.0 \pm 1.1$ & $42.7 \pm 4.0$ \\
\hline \multirow{5}{*}{4} & $00-5$ & $25.1 \pm 1.1$ & $22.3 \pm 3.4$ & \multirow{5}{*}{10} & $00-5$ & $59.7 \pm 1.5$ & $52.5 \pm 4.7$ \\
\hline & $5-10$ & $50.2 \pm 1.3$ & $32.3 \pm 4.0$ & & $5-10$ & $132.9 \pm 2.6$ & $100.3 \pm 7.9$ \\
\hline & $10-20$ & $27.3 \pm 1.0$ & $17.7 \pm 3.3$ & & $10-20$ & $61.0 \pm 1.7$ & $57.7 \pm 5.3$ \\
\hline & $20-30$ & $24.1 \pm 0.9$ & $21.2 \pm 3.0$ & & $20-30$ & $79.6 \pm 1.6$ & $72.6 \pm 5.2$ \\
\hline & & & & & $30-40$ & $48.3 \pm 1.3$ & $45.1 \pm 4.1$ \\
\hline \multirow{4}{*}{5} & $00-5$ & $16.5 \pm 0.8$ & $20.4 \pm 3.0$ & \multirow{4}{*}{11} & $00-5$ & $47.5 \pm 1.5$ & $43.4 \pm 5.2$ \\
\hline & $5-10$ & $14.4 \pm 0.8$ & $18.6 \pm 3.0$ & & $5-10$ & $26.6 \pm 1.0$ & $26.1 \pm 3.5$ \\
\hline & $10-14$ & $13.8 \pm 0.7$ & $17.9 \pm 2.6$ & & $10-20$ & $48.8 \pm 1.3$ & $43.0 \pm 4.2$ \\
\hline & & & & & $20-30$ & $138.6 \pm 2.2$ & $89.3 \pm 6.5$ \\
\hline \multirow{5}{*}{6} & $00-5$ & $24.5 \pm 1.1$ & $23.9 \pm 3.7$ & \multirow{5}{*}{12} & $00-5$ & $92.2 \pm 2.3$ & $79.4 \pm 7.4$ \\
\hline & $5-10$ & $19.9 \pm 0.9$ & $20.3 \pm 3.2$ & & $5-10$ & $34.6 \pm 1.1$ & $29.2 \pm 3.6$ \\
\hline & $10-20$ & $22.7 \pm 1.0$ & $26.0 \pm 3.3$ & & $10-20$ & $45.9 \pm 1.3$ & $33.3 \pm 4.0$ \\
\hline & & & & & $20-30$ & $35.3 \pm 1.1$ & $30.2 \pm 3.6$ \\
\hline & & & & & $30-40$ & $28.7 \pm 1.0$ & $26.8 \pm 3.4$ \\
\hline
\end{tabular}

Table 4. Activities of ${ }^{226} \mathrm{Ra}$ and ${ }^{238} \mathrm{U}$ in $\mathrm{Bq} \mathrm{kg}{ }^{-1}$ measured in nine surface samples of Kastela Bay sediments and mean values of selected radionuclides determined for open Adriatic and coastal Adriatic sediment

\begin{tabular}{cccc}
\hline & & & \\
Surface sample & Depth $(\mathbf{c m})$ & ${ }^{226} \mathbf{R a}$ & ${ }^{238} \mathbf{U}$ \\
\hline 13 & $00-5$ & $15.8 \pm 0.9$ & $19.0 \pm 3.3$ \\
14 & $00-5$ & $16.3 \pm 0.8$ & $23.2 \pm 3.1$ \\
15 & $00-5$ & $14.2 \pm 0.8$ & $29.9 \pm 3.3$ \\
16 & $00-5$ & $192.0 \pm 3.2$ & $169.1 \pm 9.6$ \\
17 & $00-5$ & $13.2 \pm 0.7$ & $24.4 \pm 2.8$ \\
18 & $00-5$ & $17.0 \pm 0.8$ & $22.1 \pm 3.2$ \\
19 & $00-5$ & $20.6 \pm 1.1$ & $30.6 \pm 3.8$ \\
20 & $00-5$ & $15.4 \pm 0.8$ & $20.4 \pm 3.0$ \\
21 & $00-5$ & $18.8 \pm 0.9$ & $24.8 \pm 3.4$ \\
$* \bar{X}_{\text {Open Adriatic }}, \mathrm{N}=48$ & $00-5$ & 19.9 & 19.1 \\
$* \bar{X}_{\text {Croatian coast, }} \mathbf{N}=51$ & $00-5$ & 19.2 & 18.2 \\
\hline
\end{tabular}


Table 5. Concentrations of selected elements in 12 sediment profiles determined by

EDXRF. Depth in $\mathrm{cm}$; Fe in \%wt, other elements in ppm

\begin{tabular}{|c|c|c|c|c|c|c|c|c|c|}
\hline Profile & Depth & $\mathrm{Pb}$ & $\mathbf{U}$ & $\mathrm{Zr}$ & $\mathrm{Cr}$ & $\mathrm{Fe}$ & Co & $\mathrm{Ni}$ & $\mathrm{Zn}$ \\
\hline \multirow{6}{*}{1} & $00-5$ & 80 & 14.1 & 125 & 110 & 3.211 & 10.5 & 90 & 422 \\
\hline & $5-10$ & 93 & 33.9 & 144 & 140 & 3.795 & 12.3 & 100 & 391 \\
\hline & $10-20$ & 96 & 16.5 & 159 & 130 & 3.221 & 10.6 & 140 & 527 \\
\hline & $20-30$ & 97 & 9.7 & 133 & 100 & 2.572 & 8.3 & 70 & 595 \\
\hline & $30-40$ & 75 & 15.3 & 148 & 140 & 3.069 & 10.1 & 90 & 432 \\
\hline & $40-55$ & 62 & 40.0 & 130 & 110 & 3.456 & 10.9 & 120 & 196 \\
\hline \multirow{5}{*}{2} & $00-5$ & 35 & 6.8 & 124 & 110 & 1.945 & 7.4 & 140 & 187 \\
\hline & $5-10$ & 32 & 13.0 & 127 & 120 & 2.260 & 8.0 & 140 & 117 \\
\hline & $10-20$ & 58 & 19.2 & 169 & 120 & 3.072 & 10.6 & 100 & 184 \\
\hline & $20-30$ & 53 & 32.0 & 173 & 140 & 3.524 & 12.4 & 110 & 157 \\
\hline & $30-40$ & 43 & 54.3 & 207 & 160 & 4.254 & 14.0 & 140 & 117 \\
\hline \multirow{5}{*}{3} & $00-5$ & 63 & 1.7 & 150 & 100 & 1.808 & 6.4 & 80 & 339 \\
\hline & $5-10$ & 74 & 1.0 & 171 & 120 & 1.870 & 6.3 & 100 & 323 \\
\hline & $10-20$ & 49 & 1.9 & 162 & 90 & 2.093 & 8.1 & 100 & 283 \\
\hline & $20-30$ & 36 & 2.0 & 121 & 100 & 1.828 & 6.4 & 110 & 184 \\
\hline & $30-40$ & 90 & 1.5 & 113 & 150 & 4.023 & 13.4 & 80 & 675 \\
\hline \multirow{4}{*}{4} & $00-5$ & 34 & 2.0 & 119 & 70 & 1.647 & 6.1 & 100 & 125 \\
\hline & $5-10$ & 31 & 2.9 & 127 & 80 & 1.751 & 6.2 & 80 & 114 \\
\hline & $10-20$ & 21 & 1.6 & 108 & 110 & 1.444 & 5.7 & 120 & 92 \\
\hline & $20-30$ & 25 & 1.9 & 117 & 100 & 1.523 & 6.0 & 140 & 107 \\
\hline \multirow{3}{*}{5} & $00-5$ & 29 & 1.8 & 122 & 90 & 1.100 & 4.5 & 60 & 59 \\
\hline & $5-10$ & 27 & 1.7 & 110 & 90 & 0.960 & 4.0 & 60 & 51 \\
\hline & $10-14$ & 33 & 1.6 & 115 & 130 & 1.028 & 4.6 & 60 & 58 \\
\hline \multirow{3}{*}{6} & $00-5$ & 29 & 2.1 & 151 & 80 & 1.384 & 5.4 & 70 & 76 \\
\hline & $5-10$ & 21 & 1.8 & 148 & 100 & 1.077 & 4.2 & 60 & 67 \\
\hline & $10-20$ & 23 & 2.3 & 168 & 70 & 1.191 & 3.9 & 40 & 70 \\
\hline \multirow{5}{*}{7} & $00-5$ & 35 & 4.1 & 151 & 80 & 1.461 & 5.0 & 50 & 155 \\
\hline & $5-10$ & 26 & 2.4 & 131 & 120 & 1.247 & 4.6 & 50 & 85 \\
\hline & $10-20$ & 30 & 2.2 & 164 & 90 & 1.489 & 5.5 & 70 & 83 \\
\hline & $20-30$ & 25 & 1.8 & 151 & 80 & 1.437 & 6.1 & 70 & 68 \\
\hline & $30-40$ & 26 & 1.8 & 139 & 70 & 1.478 & 6.0 & 110 & 66 \\
\hline \multirow{5}{*}{8} & $00-5$ & 30 & 2.0 & 135 & 90 & 1.207 & 4.4 & 60 & 114 \\
\hline & $5-10$ & 26 & 1.8 & 149 & 110 & 1.397 & 5.2 & 90 & 86 \\
\hline & $10-20$ & 26 & 1.8 & 154 & 100 & 1.353 & 4.8 & 70 & 89 \\
\hline & $20-30$ & 28 & 1.8 & 150 & 90 & 1.373 & 5.4 & 90 & 90 \\
\hline & $30-40$ & 30 & 1.7 & 150 & 90 & 1.469 & 5.8 & 80 & 94 \\
\hline \multirow{5}{*}{9} & $00-5$ & 33 & 4.7 & 156 & 90 & 1.739 & 6.3 & 60 & 146 \\
\hline & $5-10$ & 35 & 5.0 & 164 & 120 & 1.903 & 7.1 & 100 & 124 \\
\hline & $10-20$ & 38 & 4.9 & 176 & 130 & 1.844 & 7.3 & 70 & 113 \\
\hline & $20-30$ & 29 & 3.3 & 163 & 150 & 1.629 & 5.5 & 50 & 88 \\
\hline & $30-40$ & 27 & 3.8 & 166 & 80 & 1.355 & 4.9 & 50 & 63 \\
\hline \multirow{5}{*}{10} & $00-5$ & 28 & 4.7 & 141 & 87 & 1.914 & 7.1 & 92 & 158 \\
\hline & $5-10$ & 32 & 9.0 & 137 & 97 & 2.193 & 7.3 & 93 & 142 \\
\hline & $10-20$ & 36 & 5.2 & 140 & 110 & 1.946 & 7.1 & 100 & 148 \\
\hline & $20-30$ & 39 & 6.5 & 146 & 87 & 2.302 & 7.6 & 95 & 202 \\
\hline & $30-40$ & 51 & 4.0 & 144 & 80 & 2.208 & 8.1 & 110 & 265 \\
\hline \multirow{4}{*}{11} & $00-5$ & 70 & 3.9 & 135 & 85 & 1.883 & 6.8 & 85 & 394 \\
\hline & $5-10$ & 35 & 2.3 & 129 & 100 & 1.548 & 6.3 & 100 & 188 \\
\hline & $10-20$ & 313 & 3.9 & 138 & 140 & 3.894 & 11.5 & 60 & 2100 \\
\hline & $20-30$ & 249 & 8.0 & 139 & 110 & 3.715 & 12.0 & 80 & 1550 \\
\hline \multirow{5}{*}{12} & $00-5$ & 103 & 7.1 & 163 & 100 & 2.909 & 9.8 & 80 & 585 \\
\hline & $5-10$ & 130 & 2.6 & 127 & 105 & 2.533 & 8.5 & 92 & 739 \\
\hline & $10-20$ & 173 & 3.0 & 148 & 90 & 2.746 & 8.8 & 100 & 1057 \\
\hline & $20-30$ & 112 & 2.7 & 128 & 100 & 2.576 & 8.0 & 100 & 695 \\
\hline & $30-40$ & 140 & 2.4 & 126 & 99 & 2.759 & 9.0 & 102 & 972 \\
\hline
\end{tabular}


The results of XRD analyses are presented in Table 6 .

Table 6. Results of the XRD analyses of the surface sediments from Kastela Bay

\begin{tabular}{|c|c|c|c|c|c|c|c|c|c|c|c|}
\hline \multirow{2}{*}{ Mineral } & \multicolumn{11}{|c|}{ Sample No. } \\
\hline & $1 / 1$ & $2 / 1$ & $3 / 1$ & $5 / 1$ & $6 / 1$ & $7 / 1$ & $8 / 1$ & $9 / 1$ & $10 / 1$ & $11 / 1$ & $12 / 1$ \\
\hline Calcite $\mathrm{CaCO}_{3}$ & +++ & +++ & +++ & +++ & +++ & +++ & +++ & +++ & +++ & +++ & +++ \\
\hline Quartz $\mathrm{SiO}_{2}$ & ++ & ++ & ++ & ++ & ++ & ++ & ++ & ++ & ++ & ++ & ++ \\
\hline Rodochrosite $\mathrm{MnCO}_{3}$ & + & & & & & & & + & & & \\
\hline $\begin{array}{c}\text { Muscovite } \\
(\mathrm{K}, \mathrm{Na})(\mathrm{Al}, \mathrm{Mg}, \mathrm{Fe})_{2}\left(\mathrm{Si}_{3} \mathrm{Al}\right) \mathrm{O}_{10}(\mathrm{OH})_{2}\end{array}$ & & + & & & + & & & & & + & + \\
\hline $\begin{array}{c}\text { Biotite } \\
\mathrm{KMg}_{3}\left(\mathrm{Si}_{3} \mathrm{Al}\right) \mathrm{O}_{10} \mathrm{~F}_{2}\end{array}$ & & & + & & & & & & + & & \\
\hline Aragonite $\mathrm{CaCO}_{3}$ & & & & +++ & ++ & ++ & + & & & & \\
\hline Halite $\mathrm{NaCl}$ & & & & + & & + & + & & ++ & ++ & \\
\hline Siderite $\mathrm{FeCO}_{3}$ & & & & & + & & & & & & \\
\hline
\end{tabular}

+++ Abundant (app. 25-40\%); ++ Considerable (app. 10-25\%); + Subordinate to accessory

$(<10 \%)$; blank spaces-not present

\section{DISCUSSION}

\section{Mixture of fly and bottom ash}

The analyzed mixture of fly and bottom ash showed significant variability in its chemical composition. Mean elemental concentrations in the ash were elevated from 1.6 to approximately 36 times compared to the common soil concentrations. The highest enrichment was found for uranium and nickel.

Activities of ${ }^{226} \mathrm{Ra}$ and ${ }^{238} \mathrm{U}$ in the ash mixture were approximately fifty times higher than those in the common soil. In the majority of the samples of the ash ${ }^{238} \mathrm{U}$ activity was up to thirty percent lower compared to ${ }^{226} \mathrm{Ra}$. This could be explained with the fact that most of the samples were taken from the surface of the deposit with damaged protective cover or from the channel exposed to the rainwater circulation. Water circulation through the ash caused leaching of uranium that was more susceptible to the extraction from the ash by rainwater compared to ${ }^{226} \mathrm{Ra}$ causing obtained ${ }^{238} \mathrm{U} /{ }^{226} \mathrm{Ra}$ ratio being shifted toward radium. Alkaline solutions promote dissolution of the glassy components of fly ash that are unidentified host of uranium which increases uranium solubility as uranium-carbonate species. On the other hand, leachates of fly ash are rich in dissolved sulphate, and this minimizes the solubility of radium, which forms highly insoluble sulphates.

The leaching properties of the sea/rain water can be highly modified by the presence of various, naturally occurring organic complexing agents (Erdem and Tumen, 2004). Table 2 shows that only negligible amounts of $\mathrm{V}, \mathrm{Cr}, \mathrm{Pb}, \mathrm{Zn}, \mathrm{Cu}$ and $\mathrm{Ni}$ were released from flying and bottom ash either by exchangeable agent (ammonium acetate, $\mathrm{pH} 7$ ) or the sea water $(\mathrm{pH} 7)$. Organic acids were more efficient in heavy metal removal compared to ammonium acetate. The high affinity of $\mathrm{Cu}, \mathrm{Pb}$ and $\mathrm{Zn}$ for organic complexes was the reason for their higher extractability in organic acids compared to the other measured elements. The percentage of selected elements found in the extract obtained by organic acids was less than $10 \%$. Therefore, the considered elements can be assumed to be strongly bound to the ash mineral particles under the tested conditions. On the contrary, it was found that uranium could be easily mobilized from the ash. A significant amount of the total uranium was extracted from flying and bottom ash by all leaching agents, except ammonium acetate which removed only $1.6 \%$ of the total U. Removal efficiency varied from $17.2 \%$ in the case of EDTA to over $50 \%$ in the case of oxalic acid. Results show that almost $40 \%$ of the total uranium could be mobilized from flying and bottom ash by the sea water. 


\section{Sediment samples}

Dumping the mixture of fly and bottom ash directly into the sea resulted in extremely high activities of ${ }^{226} \mathrm{Ra}$ and ${ }^{238} \mathrm{U}$ in sediment profiles 1 and 2 reaching maximum values in the deepest segments. Maximum ${ }^{238} \mathrm{U}$ activity was approximately 32 times higher and ${ }^{226} \mathrm{Ra}$ approximately 40 times higher than the mean value determined for Adriatic sediments. Quite expectedly, elevated values of these two radionuclides were also found in the profiles 9, 10, 11 and 12 placed near the ash deposit and in the surface sediment sample 16 located near the "Adriavinil" factory (Tables 3 and 4).

According to Shapiro-Wilks $\mathrm{W}$ test $\mathrm{U}, \mathrm{Pb}$ and $\mathrm{Zn}$ deviated significantly from the normal distribution in all sediment segments, while $\mathrm{Zr}, \mathrm{Cr}$ and Fe showed disturbance in normal distribution only in the first segment and $\mathrm{Co}$ in the fourth sediment segment. Fe, Co and $U$ showed linear increase with increasing depth exhibiting the greatest concentrations in the fifth segment. $\mathrm{Cr}$ concentrations decreased from the first to the second segment and further increased linearly toward the fifth segment while concentrations of $\mathrm{Ni}$ increased from the first to the second segment, decreased toward the third segment and increased further reaching maximum concentration in the fifth segment. $\mathrm{Pb}$ showed maximum values in the second segment and decreased linearly until it reached minimum values in the fifth segment. $\mathrm{Zr}$ and $\mathrm{Zn}$ showed the most irregular concentration patterns decreasing from the first to the second segment, reaching maximum values in the third segment, dropped to the fourth segment and increased again toward the fifth segment. Results of one-way ANOVA after logarithmic transformation of variables showed that obtained variability in the elemental concentrations among the segments was significant only for the variables $\mathrm{Zr}$, Fe and $\mathrm{Co}$. All three elements showed the greatest concentrations in the fifth segment (depth $30-40 \mathrm{~cm}$ ) which pointed to a larger input of terrestrial material like the mixture of fly and bottom ash and a flysch material into predominant carbonate sediments.

XRD analyses results (Table 6) conducted on the surface sediment samples pointed to a predominant carbonate sedimentation with calcite and aragonite as predominant minerals. Presence of considerable amount of quartz and traces of phyllosilicates pointed to terrigenous fluxes from the surrounding areas into the Bay.

The degree of the pollution of the Kastela Bay sediments was estimated by dividing mean and maximum concentration of the elements $\mathrm{Pb}, \mathrm{Cr}, \mathrm{Fe}, \mathrm{Ni}$ and $\mathrm{Zn}$ for each sediment segment with background concentration determined in Punat Bay sediments (Mikulic et al., 2004) which have similar origin and mineralogical composition as Kastela Bay sediments. The highest enrichment compared to background values was found for $\mathrm{Zn}$ (35.6 times), $\mathrm{Pb}$ (16 times), $\mathrm{Cr}$ (9.1 times) and $\mathrm{Ni}$ (4 times). $\mathrm{Pb}$ and $\mathrm{Zn}$ showed the greatest enrichment in the third sediment segment $(10-20 \mathrm{~cm}), \mathrm{Cr}$ in the first and $\mathrm{Ni}$ in the fifth segment. Maximum enrichment with Fe was 2.9 times. As expected, the highest concentrations of total uranium were determined at the positions 1 and 2 located in the vicinity of the ash deposit site under the constant influence of ash dumping into the sea and leaching from the ash deposit. Maximum concentrations of heavy metals were determined in the samples taken at the points 11, 12, 1 and 3 the most exposed to the various anthropogenic sources. Measured concentrations of heavy metals $\mathrm{Zn}, \mathrm{Pb}, \mathrm{Cr}$ and $\mathrm{Ni}$ from that area were significantly higher than those reported by Mikulic and others 1994 and Lazzari and others 2004 for the Central Adriatic area. Presented results were in agreement with those reported by Bogner and others 1998 and Ujevic and others 2000 for Kastela Bay. Anthropogenic sources contributed either through untreated waste waters or through emission into the air followed by wet and dry deposition of emitted particles containing significant amount of heavy metals. Nearby shipyard activity should also be considered as a source of lead, zinc and copper originating from antifouling paints and coatings. The similar effect could be expected from the facility for boats 
repairing and finishing which started to operate few years ago. Elevated level of $\mathrm{Zn}, \mathrm{Fe}$ and $\mathrm{Cr}$ was also the result of discharge of untreated electroplating waste waters from electroplating facilities situated in Vranjic into Jadro River. The maximum concentrations of heavy metals were found in the deeper sediment segments deposited in the period of the highest industrial production and the negligible care to the environment.

\section{CONCLUSIONS}

Presented results indicated that unregulated dumping of the mixture of fly and bottom ash enriched in radionuclides and heavy metals as well as other anthropogenic sources (industry, traffic, waste waters) caused the severe pollution of Kastela Bay sediments. Maximum ${ }^{238} \mathrm{U}$ activity was approximately 32 times higher and ${ }^{226} \mathrm{Ra}$ approximately 40 times higher in the Kastela Bay sediment compared to mean value determined for Adriatic sediments, while maximum enrichment with heavy metals ranged from 4 to over 35 times compared to background values. Investigated flying and bottom ash showed a significant variability in their chemical composition. The highest values compared to soil concentrations were found for $\mathrm{U}$ and $\mathrm{Ni}$. Extractable heavy metal portion under all tested conditions was found to be less than $10 \%$, except for the total uranium which showed the high possibility for leaching either by the marine water or in weak organic acids.

\section{REFERENCES}

Bogner, D., Juracic, M., Odzak, N. and Baric, A. (1998), Trace metals in fine grained sediments of the Kastela bay, Adriatic sea, Water Science and Technology, 38(11), 169-175.

Erdem, M. and Tumen, F. (2004), A study on dissolution properties of the sludges from $\mathrm{Cr}(\mathrm{VI})$ reduction-precipitation processes, Journal of Environmental Science and Health, Part AToxic/Hazardous Substances and Environmental Engineering, 39(6), 253 - 67.

De Lazzari, A., Rampazzo, G. and Pavoni, B. (2004), Geochemistry of sediments in the Northern and Central Adriatic Sea, Estuarine, Coastal and Shelf Science, 59(3), 429-440.

Marinez-Lobo, A. and Palomares, J. (1991), On the determination of ${ }^{226} \mathrm{Ra}$ in soils and uranium ores by direct gamma-ray spectrometry, Journal of Radioanalytical and Nuclear Chemistry, 147(2), 225-234.

Mikulic, N., Degobbis, D., Picer, M., Raspor, B., Sipos, L., Sobot, S, Zvonaric, T. and Precali, R. (1994), Monitoring programme of the eastern Adriatic coastal area. Report for 1983-1991, MAP Technical Reports, Series No. 86, UNEP, Athens.

Mikulic, N., Orescanin, V., Legovic, T. and Zugaj, R. (2004), Estimation of heavy metals (Cu, Zn, $\mathrm{Pb}$ ) input into the Punat bay, Environmental Geology, 46(1), 62-70.

Murray, A.S. and Aitken, M.J. (1988), Analysis of low-level natural radioactivity in small mineral samples for use in thermoluminescence dating, using high-resolution gamma spectrometry, International Journal of Applied Radiation and Isotopes, 39(2), 145-158.

Orescanin, V., Barisic, D., Mikelic, L., Lovrencic, I., Rubcic, M., Rozmaric Macefat, M. and Lulic, S. (2004a), Environmental contamination assessment of the surroundings of the ex-Sibenik's ferro-manganese smelter, Croatia, Journal of Environmental Science and Health, Part AToxic/Hazardous Substances and Environmental Engineering, 39(9), 2493-2506.

Orescanin, V., Katunar, A., Kutle, A. and Valkovic, V. (2003), Heavy metals in soil grape and wine, Journal of Trace and Microprobe Techniques, 21(1), 171-180.

Orescanin, V., Lulic, S., Pavlovic, G. and Mikelic, L. (2004b), Granulometric and chemical composition of the Sava river sediments upstream and downstream of the Krsko nuclear power plant, Environmental Geology, 46(5), 605-614.

Ujevic, I., Odzak, N. and Baric, A. (2000), Trace metal accumulation in different grain size fractions of the sediments from a semi-enclosed bay heavily contaminated by urban and industrial wastewaters, Water Research, 34(11), 3055-3061. 